\title{
Summary
}

Andrzej Szmyt, Anna Rytel-Warzocha. Europeanization of Law in Poland from the point of view of Constitutional Law.

The article is devoted to the challenges and problems concerning the accession of the Republic of Poland in the European Union. The authors analyze the constitutional bases of the accession to the EU as well as basic legal acts which have regulated the mutual relations between Poland and the EU.

The Republic of Poland has acceded to the European Union by virtue of the Accession Treaty which was signed on 16 April 2003 in Athens and entered into force on 1 May 2004.

From the point of view of constitutional law, there were several issues which concerned the preparation for EU accession at the national level. They were especially related to: 1) the establishment of legal basis allowing for the integration the law of the European Union with Polish constitutional law, 2) the harmonization of the Polish legal system with the legal order of the European Union, 3) the establishment of the ratification procedure of the Accession Treaty. All these issues required new legal regulations to be implemented to the Constitution. That was why the new Constitution of the Republic of Poland adopted on 2 April 1997 included two provisions relevant for the issues concerning the integration with the European Union - art. 90 and art. 91 para

The main problems presented in the article concern the relation of Polish national law (in particular the Constitution) to the sources of primary and secondary European law, the harmonization of Polish law with EU law (constitutional amendments referring to "EU matters", necessary amendments of statutory law and the provisions of the Standing Orders of the Sejm and the Senate), as well as institutional changes in Poland determined by the EU membership.

Key words: Constitutional law, EU accession, Poland, accession treaty, EU law.

DOI: 10.36695/2219-5521.3.2019.43

UDC 342.1

M. MGELADZE, N. PHUTKARADZE

Mariam Mgeladze, MA, LL.M, Lecturer of Batumi Maritime State Academy*

ORCID: 0000-0002-9354-2620

Nugzar Phutkaradze, Ph.D. in Law**

ORCID: 0000-0002-2739-7664

\section{THE MARITIME INDUSTRY AND THE ROLE OF WOMEN SEAFARERS: A LEGAL REGULATORY FRAMEWORK}

\section{Introduction}

The Maritime industry is a global service industry, where the acceptance of women has taken much longer than in other industries. In some perspectives, the maritime industry is considered more conservative than other global industries, especially where the roles of women compared to that of men are very low. As a result, one of the biggest world service industry has become male-dominated. As history has shown, women were not accepted on board of ships and even more so, excluded from the shipping business. Additionally, existing traditional, religious, social and customary views of the industry whereby females are unemployable, has had a particularly strong influence on a woman's status in the maritime industry. At present, there is a great need to establish comprehensive policy and strategy in order to promote women's entrance into the shipping industry. As a result, there have been positive responses to international calls for more females to join the seafaring profession. However, in Georgia, very few women are employed aboard ships where technical and/or engineering work takes place. Furthermore, the growth rate is rather slow, even with advancements in ship technology, which have made seafaring less strenuous than it used to be.

Gender pay gaps are still omnipresent, but shrinking ${ }^{1}$. The most common and enumerated arguments against the employment of women in the maritime industry are physical efficiencies of women, the lack of psychological ability to work onboard the vessel, vulnerability and emotional instability and improper social conditions on vessels, questions regarding professional qualifications and common opinions that ship is not an appropriate workplace for women and/or women shall not work at sea. Nevertheless, it is necessary to point out that all aforementioned arguments existed previously in society and provide stereotypical perceptions of women. In Georgia, females are seldom encouraged to pursue a career in the maritime industry, specifically due to the fact that such a job is risky and unsafe, moreover they are expected to play the natural role of maintaining a favorable emotional environment in society. Nowadays, this tendency has slowly begun to change in Georgia, and most importantly, in a positive way.

The first chapter makes a brief overview of the facts which relatively lows the role of women on board of the ship; The second chapter introduce the international legal regulatory instruments in line with the international fun-

(C) M. Mgeladze, N. Phutkaradze, 2019

\footnotetext{
* Маріам Мгеладзе, викладач Батумської морської державної академії

** Нугзар Путкарадзе, кандидат юридичних наук
} 
damental principles of human rights, inclusive legal documents by IMO and ILO; The third chapter discuss the role of international organizations, shipping companies and academia in order to promote women in maritime industry. Last chapter covers recommendation and final conclusions.

\section{Chapter 1. An overview of women in maritime industry}

While being ashore or on board of the ship, women mariners meet additional barriers with different nature and origin. For example, women are challenged to prove their ability to work harder, taking more demanding tasks ${ }^{2}$. Also, they are dealing with a decision from one of the main issues in the maritime field- ship-owners who stereotypically believe the industry should not employ women. Furthermore, women may also be denied facilities or equipment available to male workers. Women working in a predominantly male, and often hostile, environment have to confront discrimination, sexual harassment, bullying and violence in their workplace on board ships 3 . Automatically, this attitude excludes female participants from the shipping industry, which leads to the problem of equal chances for women and men to be presented in maritime field. Beyond the shadow of a doubt, underlined reasons at the end of the day have had a strong negative influence on women status' and over and above that, destroyed trust in the maritime industry.

Today's picture shows, that the percentage of women engaged in maritime industry is still very small based on statistical information. Accordingly, Seafarers' Right International Center for advancing the legal protection of seafarers approximates that 1.5 million seafarers daily serve on a worldwide fleet of over 100,000 ships that transport over $90 \%$ of world trade. While ILO considers that more than 1.2 million seafarers operate ships. Current statistics of International Transport Workers' Federation show that women make up only an estimated two percent of the world's maritime workforce. In accordance with ILO, in the cruise line sector, women represent $17-18 \%$ of the workforce. Moreover, $94 \%$ of women are employed on passenger ships (with $68 \%$ on ferries and $26 \%$ on cruise ships) and $6 \%$ are employed on cargo vessels (i.e., container ships, oil tankers, etc.) ${ }^{5}$. However, women are generally employed as hotel staff on passenger ships. As the statistical information shows, $51.2 \%$ of women at sea come from OECD countries, $23.6 \%$ from Eastern Europe, $9.8 \%$ from Latin America and Africa, $13.7 \%$ from the Far East, and $1.7 \%$ from south Asia and the Middle East ${ }^{6}$. In the majority of 67 countries with data from 2009 to 2015, less than a third of senior-and middle-management positions were held by women (E/2017/66) ${ }^{4}$. According to the $2015 \mathrm{BIMCO} / \mathrm{ICS}$ manpower report, the percentage of women seafarers was still only 1 per cent. This reflects that women's participation in seafaring jobs continues to be as low as it was 25 years ago. However, history records exceptions of women who achieved success in maritime industry. ${ }^{5}$

The 2030 United Nations Development Goals (UNSDGs) present their perspectives on gender equality in the maritime sector. In particular Goals 4, 5 and 8 are related to the advancement of women in the maritime and ocean professions. In particular, UNSDG Goal 4 aims to ensure inclusive and equitable quality education and promote lifelong learning opportunities for all. Goal 5 intends to achieve gender equality and empower all women and girls. Goal 8 addresses decent work and economic growth issues. The empowering of women will become sustainable if the maritime community starts to drive changes, moving from promise to action, and aiming to achieve concrete outcomes $^{6}$. It needs support from a consortium of main players, including International organizations, state, maritime companies, civil society and academia.

\section{Chapter 2. The Legal Regulatory Framework of Gendering Maritime Industry}

Highlighting the role of women, employment on board of the ship and participation in the maritime industry is part of the international community's strategic direction ${ }^{7}$. In order to ensure that these goals are implemented and enforced, several international maritime law conventions have been adopted. Overall, they are an effective starting point in pushing forward reforms. Moreover, such conventions created a general legal regulatory framework for contracting states. The aforementioned goals have been clearly addresses by STCW 95. Namely, resolution 14 constitutes "promotion of the participation of women in the maritime industry" 8 . This resolution invites government to give special consideration to securing equal access for men and women in all sectors of the maritime industry. Also, and more importantly, it highlights the role of women in the seafaring profession and to promote their greater participation in maritime training and at all levels in the maritime industry.

Gender equality issues are not exclusive to the maritime industry. They are also omnipresent in the legal sphere. Largely, the issues begin with terminology used in legal documents with respect to gender equality. As the maritime industry had for a long-time been a male-dominated industry, national and international legal documents used the term seaman, which did not legally recognize engagement of women into maritime sector. It followed that enacted terminology in law was not gender sensitive, and the legal regulatory framework was characterized as discriminatory on gender-biased grounds. Furthermore, since states have an obligation, as a contracting party, to implement and ratify international agreements ${ }^{22}$, translations of such documents for implementation often did not consider gender-biased terminology which often times lead to male-dominated interpretations. Only in the 294th session of the International Labour Organization (ILO) in 2005, began to replace terms such as "seaman" with the more gender-neutral "seafarer"9.

A lack of specially designated and globally applicable universal maritime legal instruments with respect to gender equality and gender discrimination against women, leaves any legal recourse to be done through international law.

The right of equality is also guaranteed by the Universal Declaration of Human Rights, which consolidate principles of equality before the law and the resulting prohibition of discrimination by the virtue of article 1,2 and 7.10 
Article 14 of The European Convention on Human Rights, 1950 states that the enjoyment of the rights and freedoms set forth in this Convention shall be secured without discrimination. ${ }^{11}$

The right to equality and freedom from discrimination is also protected by various provisions, such as article 2(1), 3 and 26 of the International Covenant on Civil and Political Rights. ${ }^{12}$ Moreover, articles 2(2) and 3 of the International Covenant on Economic, Social and Cultural Rights [48], 1966, underlines State parties obligation "to guarantee the rights and to ensure the equal right of men and women. Additionally, article 7(a) (i) and 7(c) secures "fair wages and equal remuneration for work of equal value without distinction and equal opportunity for everyone to be promoted in his employment to an appropriate higher level, subject to no considerations other than those of seniority and competence".

In this respect, the Convention on the Elimination of All Forms of Discrimination against Women, 197913, describes "discrimination against women" as meaning "any distinction, exclusion or restriction made on the basis of sex which has the effect or purpose of impairing or nullifying the recognition, enjoyment or exercise by women, irrespective of their marital status, on a basis of equality of men and women, of human rights and fundamental freedoms in the political, economic, social, cultural, civil or any other field". Under article 2 and 11 of the convention States undertake a series of measures to end discrimination against women in all forms. ${ }^{14}$ In this respect, subsections of Article 11, (e) and (f) grants the fundamental social security principles in terms of prevention of discrimination against women.

Interestingly, social security as a right is also protected and state obligations are also set by the article 22 and 23 of Universal Declaration of Human Rights, $1950 .{ }^{15}$ Furthermore, Articles 6, 7 and 9 of International Covenant on Economic, Social and Cultural Rights equally impose state obligations and underline parties to the Covenant recognize the right to work. ${ }^{16}$

In this regard, it is interesting to analyze the legal regulatory framework of Maritime Labour Convention $(M L C), 2006$ as well. Article III and Article IV of the MLC convention also recognizes fundamental principles by imposing an obligation to eliminate discrimination with respect to employment and occupation. ${ }^{16}$ Importantly, Rights and freedoms defined by MLC equally applies to men and women seafarer by the virtue of the Article II (f).

It has a great importance to analyze Geneva Declaration on Human Rights at Sea, Version 1, 2019. More importantly, it rests on four fundamental principles: 1 . Human rights apply at sea to exactly the same degree and extent that they do on land. 2. All persons at sea, without any distinction, enjoy human rights at sea. 3 . There are no maritime specific rules allowing derogation from human rights standards. 4. All human rights established under treaty and customary international law must be respected at sea. ${ }^{17}$

In this chapter, an international legal instrument in regard of equality and gender discrimination has been briefly discussed. The existed framework of International law guarantees women enjoyment of their right and obliges state to enact the relevant law. In opposite, there are lack of specially designated and globally applicable universal maritime law instruments which creates a protective approach through establishing a comprehensive legal regime for women in maritime sector in regard of gender equality and discrimination against women.

\section{Chapter 3. The Role of International organizations, private companies and academia}

International organizations have established several campaigns in order to attract more women to the maritime business. One such campaign is "Go to Sea!", which was established in November 2008 in cooperation with the ILO, the Baltic and International Maritime Council (BIMCO), International Chamber of Shipping/International Shipping Federation (ICS/ISF), International Association of Dry Cargo Shipowners (INTERCARGO), International Association of Independent Tanker Owners (INTERTANKO) and the International Transport Workers Federation (ITF). The campaign's specific aim was to promote seafaring as an attractive option for young people, not only at sea but also in the broader maritime industry. With the "Go to sea!" initiative, IMO had opened an umbrella under which industry and Governments can mount their own campaigns to improve seafarer recruitment. ${ }^{18}$

Furthermore, the United Nations contribution to the cause of promoting women to join seafaring has been invaluable. Equality and empowerment of women are one of the United Nations' most important targets. ${ }^{19}$ As a result, the Commission on the Status of Women ${ }^{20}$ was established by Council resolution 11(II) of 21 June 1946 and the Convention on The elimination of Discrimination Against Women was adopted in 1979 by the UN General Assembly ${ }^{21}$. Then, a series of UN conferences continued the campaign, Copenhagen 1980 [38], Nairobi, $1985^{22}$ and in 1995 the Fourth World Conference on Women in Beijing. Lastly, the United Nations set up a development fund the United Nations Development Fund for Women (UNIFEM) ${ }^{23}$ and an International Research and Training Institute for the Advancement of Women (INSTRAW) ${ }^{24}$.

Another important organization defending women's rights has been the International Labour Organization, which was designated an institution of the UN in 1919.25 Since that time, it has promulgated more than 40 Conventions and more than 30 Recommendations in order to protect seafarers and their rights and has taken important steps in advancement of women. ${ }^{26}$ The resolution concerning ILO action for women workers (1991) requested governments to include more women in delegations sent to ILO conferences and meetings. ${ }^{27}$ In Revised Version of the Maternity Protection Convention (1952), ILO recommended maternity leave, on production of a medical certificate, with a minimum duration of twelve weeks, as well as woman should be entitled to medical benefits, which includes pre-natal and post-natal as a right to all women whether married or unmarried. ${ }^{28}$ The ILO has also developed the Decent Work Agenda which promotes job creation, rights at work, social protection and social dialogue, with gender equality highlighted as a crosscutting objective ${ }^{29,30}$. 
The combined aforementioned conventions, recommendations and resolutions demonstrate the ILO's effort promote, protect and improve women's rights. It has to be underlined that, the basic principles of gender equality, employment, maternity protection, work and family matters, working conditions are subjects of number of international legal instruments already provided by ILO. These include: Equal Remuneration Convention, 1951; Equal Remuneration Recommendation, 1951; Discrimination (Employment and Occupation) Convention, 1958; Discrimination (Employment and Occupation) Recommendation, 1958; Workers with Family Responsibilities Convention, 1981; Maternity Protection Convention, 2000; Employment Policy Convention, 1964; Employment Policy Recommendation, 1964; Employment Policy (Supplementary Provisions) Recommendation, 1984; Human Resources Development Convention, 1975; Human Resources Development Recommendation, 1975; Termination of Employment Convention; Termination of Employment Recommendation; Maternity Protection Convention (Revised), 1952; Maternity Protection Recommendation, 1952; Maternity Protection Convention, 2000; Maternity Protection Recommendation, 2000; Workers with Family Responsibilities Convention, 1981; Workers with Family Responsibilities Recommendation, 1981; Night Work (Women) Convention (Revised), 1948; Protocol of 1990 to the Night Work (Women) Convention (Revised), 1948; Night Work Convention, 1990; Night Work Recommendation, 1990; Occupational Safety and Health Convention, 1981; Protocol of 2002 to the Occupational Safety and Health Convention, 1981; Occupational Safety and Health Recommendation, 1981. However, most ILO instruments are not enforced by countries around the world.

The promotion and advancement of women is one of the main goals of the International Maritime Organization as well. In 1988, the IMO approved the "Strategy of the Integration of Women in the Maritime Sector", which addressed human resources development and capacity-building ${ }^{31}$. The development for women became a mainstream element of the Organization's Integrated Technical Co-operation Programme (ITCP), inter alia, under the Technical Co-operation Committee (TC). Under the Technical Co-operation Committee ${ }^{32}$ two important initiatives were approved: 1) the IMO Medium Term Plan for the Integration of Women in the Maritime Sector, and 2) Action Programme for Equal Opportunities and Advancement of Women in the Maritime Sector. These initiatives were then implemented in the IMO's Programme on the Integration of Women in the Maritime Sector (IWMS) 33,34 . At-present, the IMO continues to support the participation of women in both shore-based and sea-going posts, in order to achieve gender equality and empower all women and girls under the slogan: Training-Visibility-Recognition. In order to promote women participation, the IMO also urges the shipping industry to address requirements for separate accommodation and other facilities for women seafarers, as well as guarantee that a core minimum of two female seafarers are employed on any given ship with effective support systems in place.

Shipping companies have a main role to play in eliminating gender discrimination on board of ships as well as with respect to employment and working agreements. In order to reduce potential sexual discrimination against females, achieve balance and harmony between different genders in the work environment, and create gender friendly working conditions, shipping companies need to adopt and provide a gender familiarization programme and sexual harassment policy. The requirement derived from STCW and the law (international and/or national) regarding equality has to be a part of agreement. In addition, companies shall provide a better standard of working environment, the granting of medical leave, a pregnancy policy and reinstatement of employment for women and men ${ }^{35}$.

Another major issue is maritime industry education. There are few maritime educational institutes where it is possible to get maritime education and prepare a seafarer for navigation, namely LEPL- Teaching University- Batumi State Maritime Academy ${ }^{36}$ Ltd Batumi Navigation Teaching University Georgia ${ }^{37}$, LLC-Batumi High Maritime Engineering School ANRI ${ }^{8}$, and Maritime training center "EQUATOR" LTD 39 . There are two other structural units which also play key role in education and training of seafarers such as a structural unit of Batumi State Maritime Academy, namely Seafarers Training and Certification Center ${ }^{40}$ and Vocational Training Center ${ }^{41}$. Georgia has a ports, namely Batumi Sea Port, Poti Sea Port, Kulevi Oil Terminal and Supsa Terminal ${ }^{42}$. In Georgia, for the effective implementation of organizational and legal instruments in the maritime field derived from national and international requirements is responsibility of MTA under the auspices of the Ministry of Economy and Sustainable Development of Georgia ${ }^{43}$. Despite of the fact that all those institutions are created women engagement into this sector is still very low.

In line with its international commitments, Georgia has adopted legislative and policy reforms to foster gender equality and to combat violence against women. In Georgia, the right of equality is guaranteed by the Constitution of Georgia ${ }^{44}$, Law of Georgia on Gender Equality ${ }^{45}$, Law of Georgia on Elimination of all form of Discrimination ${ }^{46}$. This fundamental principle is also enshrined in the Law of Georgia on High Education ${ }^{47}$, Law of Georgia on Vocational Education and Training 48 , Law of Georgia on Education and Certification of Seafarers ${ }^{49}$. In Georgia, it has been created the Inter-Agency Commission on Gender Equality, Violence against Women and Domestic Violence, Gender Equality Council, which is mandated to review and evaluate gender impact assessments on all proposed legislation. Moreover, the Government approved an Action Plan on Gender Equality Policy (2018-2020) ${ }^{50}$, one component of which aimed to secure "gender equality". The National Action Plan on the Protection of Human Rights (2018-2020) contains as well a section on "Gender equality and women's empowerment", but mission does not address workplace discrimination, including the need for equal pay legislation, discriminatory vacancy advertisements, gender segregation in the labour market, the lack of basic services, or other key issues impeding women's economic empowerment ${ }^{51}$.

Georgia considers that education, training and certification are important key elements in empowering women's participation in Georgia. Consequently, educational institutes widely opened the door for young women to 
provide them education and training together with men in accordance with the STCW Convention. In turn, this has enabled women to acquire the highest level of training that shipping industry demands. Georgia's training centers are now equipped with modern training-simulation and modern laboratories. Also, vocational educational training centers provide educational programs in accordance with regulations, as well as local and international market requirements. In short, Maritime institutions providing maritime education are ready to train women seafarers, but are unable to guarantee employment aboard a ship once graduated. However, the amount of women lecturer and graduated women seafarers, successfully employed on board of the ship reminds still very low.

In this chapter we discussed several UN, IMO, ILO initiatives and legal instruments that has been adopted in order to promote women engagement in maritime sector. It also talks about shipping companies, academia and legislation of Georgia. Despite the facts that a lot of international organizations take an active role of mentors to encourage new blood into the industry through development of a significant approach on motivating women to orientate towards a maritime carrier, women engagement in this sector are still very low. One of main key element is weak of practice, enforcement policy and proper legal frameworks, including labour regulatory standards.

\section{Chapter 4. Recommendations}

In order to empower women to join the maritime sector, a number of steps should be taken:

- Gender equality plans/policies should be established stipulating the specific equality objectives to be reached, the strategies and practices to be adopted to attain them and the establishment of effective monitoring and assessment systems. Gender equality plans should be transparent and, where applicable, the subject of negotiations with workers' representatives;

- A gender equality policy addressing problem of sexual harassment shall be adopted by state and shipping companies and shall be an integral part of Ship Management System. The enforcement mechanism shall be also covered by the policy. A strict liability regime and responsibilities shall also be defined;

- Improvement and adoption of effective, protective legal instruments with respect to social security, gender equality and women rights is vital. Also, the IMO should provide technical and legal assistance to Georgia for purposes of incorporation into national law. Special provisions in regard of gender discrimination and protection of women from sexual harassment have to be an integral part of employment contract as well;

- Civil Society, Teaching Universities, Shipping Companies, State agencies shall collaborate together and develop initiatives, trainings, programmes, including exchanging programmes projects, work forum, conferences;

- Academia shall support research, studies and academic works regarding women seafarers. Maritime educational institutions shall develop curriculums using a systematic and gender-sensitive approach, includes specific courses on women leadership, career building, mentoring and networking, capacity building to increase awareness and promote equality amongst next generation of maritime professionals. Universities can also help connect women seafarers with other women in managerial positions. Maritime education and training for women shall be supported and guaranteed. Also, educational institutions shall provide enough capacity, infrastructure and facilities to educate and train women;

- Social awareness regarding this issue should be raised. For example, positive experiences of companies employing women seafarers should be supported, shared and encouraged by State, media and social networks.

- Diversity of crew members as a main principle and value of the industry has to be embraced by the maritime sector itself, academia and shipping companies;

- Living and working conditions defined by international and national law shall be improved. This will include adopting gender sensitive working atmosphere on board ships, as well as constructing accommodations for women with disabilities;

- Shipping companies shall develop a uniform set of training and educational programs, including a gender familiarization programme and practical material for seafarers in order to effectively improve their skills; Maritime companies need to start social responsible campaigns first with their own employees, by removing gender barriers at women seafarer employment;

- Shipping companies should upgrade Human Resources policies by making them gender-friendly and also by ensuring policies on gender equality and cultural awareness are communicated both on board their ships, at the onshore headquarters of the company, stakeholders and community through website and social media;

- A specific measure should be developed, which will require employers of public and private sector, to develop internal mechanisms for handling complaints of harassment and sexual harassment. The establishment of a protocol for filing complaints of harassment and sexual harassment; Sanction to sexual harassment shall be amended, foreseeing liability for employers failing to respond to complaints, including through the imposition of disciplinary measures;

- The Domestic Violence Law, Administrative Law and criminal legislation should be amended to provide effective protection mechanism of victims of violence.

\section{Conclusion}

I believe that women participation and engagement in maritime industry an unstoppable trend. Promotion and preparation of women through education will lead the maritime industry to sustainable development and transformation. In order to attract women into the business the working environment shall be friendly and safe. Successful promotion means holding stakeholders accountable, engaging executive sponsors, the relevant governmental bodies to support the changes before, during and after its implementation. It also means enjoyment and protection of rights 
and legal interest, safe, sound living and working environment, equal employment opportunities and payment, legal regulatory policy and effective enforcement and protection procedures.

It is very important that women are understood as a strategic human resource in the maritime industry. Qualified women seafarers as a human sources, with a desire to seek a career in the maritime industry is a potential supply of labour for maritime sector. Importantly, they are resource for their country in developing sustainable robust maritime policy through strengthening regional competencies and capacities to address the requirements of international conventions and instruments.

Education of women will fuel sustainable economies and will benefit society as a whole. Effectively promoting gender equality means recognizing that women are diverse in the roles they play, as well as in age, social status, ability, geographic location and educational attainment. Therefore, academia and teaching universities should be open for women, to help them achieve high levels of education and enable career development.

The private sector also plays a key role in advancing women's interests in the maritime business. Employment of women mariners by shipping companies and working agreements should contain provisions about prohibition of gender discrimination against women and inclusive international law standards.

Last but not least, international organizations who put enormous efforts in promotion of women in maritime industry shall continue their activity in this direction. Therefore, it is very important to reinforce the international standards, and support its implementation into national law. In this regard, any adopted international instrument has to contain gender neutral and sensitive terminology.

${ }^{1}$ Esteban Ortiz-Ospina, Six key facts about the gender pay gap, February 19, 2018, available https://ourworldindata.org/six-factspay-gap, accessed at 15.02.2019.

2 Dragomir Cristina, Felicia Surugiu (2013). Seafarer women- Perception of the Seafaring Career, Department of Management in Transports Constanta Maritime University No.104, p.16, Constanta, ROMANIA, available http://www.wseas.us/e-library/conferen ces/2013/Brasov/EPLS/EPLS-01.pdf

${ }^{3}$ ITF Seafarers: Women Seafarers, https://www.itfseafarers.org/ITI-women-seafarers.cfm, accessed at 18.12.2018.

${ }^{4}$ Dragomir Cristina, Felicia Surugiu (2013). Seafarer women- Perception of the Seafaring Career, Department of Management in Transports Constanta Maritime University No.104, p.16, Constanta, ROMANIA, available http://www.wseas.us/e-library/conferen ces/2013/Brasov/EPLS/EPLS-01.pdf

5 Dragomir Cristina, Felicia Surugiu (2013). Seafarer women- Perception of the Seafaring Career, Department of Management in Transports Constanta Maritime University No.104, p.16, Constanta, ROMANIA, available http://www.wseas.us/e-library/conferen ces/2013/Brasov/EPLS/EPLS-01.pdf

${ }^{6}$ Dragomir Cristina, (2018). Gender in Maritime Transport - A Scientific Literature Overview. Ovidius” University Annals, Economic Sciences Series Volume XVIII.

7 Aggrey, Hannah Aba, (2000). "Women in the maritime industry: a review of female participation and their role in Maritime Education and Training in the 21st century". World Maritime University Dissertations. 383, P. 56

${ }^{8}$ Gender equality, available at https://www.unfpa.org/gender-equality, https://www.un.org/en/sections/issues-depth/gender-equa lity/ and https://www.un.org/womenwatch/daw/news/rights.htm accessed at 04.03.2019.

${ }^{9}$ Goal 5: Achieve gender equality and empower all women and girls, Goal 4 and 8, available at https://www.un.org/sustainable development/gender-equality, available at https://www.un.org/sustainabledevelopment/gender-equality/, accessed at 04.03.2019.

${ }_{10}$ UN Women, Gender Mainstreaming, Concepts and Definitions, available https://www.un.org/womenwatch/osagi/conceptsan definitions.htm, accessed on 09.03.2019.

${ }_{11}$ Constitution of Georgia, available https://matsne.gov.ge/en/document/view/30346?publication=35

12 International Convention on Standards of Training, Certification and Watch keeping for Seafarers 95, Resolution 14.

13 Maternity Protection Convention (Revised), 1952 (No. 103), available at https://www.ilo.org/dyn/normlex/en/f?p=NORML EXPUB:12100:0:NO:P12100_ILO_CODE:C103

${ }^{14}$ ITF Seafarers: Women Seafarers, https://www.itfseafarers.org/ITI-women-seafarers.cfm, accessed at 18.12.2018.

15 European Convention on Human Rights, https://www.echr.coe.int/Documents/Convention_ENG.pdf

16 International Covenant on Civil and Political Rights, https://www.ohchr.org/en/professionalinterest/pages/ccpr.aspx

17 The Convention on the Elimination of All Forms of Discrimination against Women (CEDAW), https://www.un.org/women watch/daw/cedaw/

18 Universal Declaration of Human Rights, available at https://www.un.org/en/universal-declaration-human-rights/

${ }^{19}$ International Covenant on Economic, Social and Cultural Rights, https://www.ohchr.org/en/professionalinterest/pages/ cescr.aspx

${ }_{20}$ Maritime Labour Convention (MLC), 2006, https:/www.ilo.org/wcmsp5/groups/public/_-ed_norm/_-normes/documents/ normativeinstrument/wcms_090250.pdf

21 International Covenant on Economic, Social and Cultural Rights, https://www.ohchr.org/en/professionalinterest/pages/ cescr.aspx

22 "Go to sea!" A campaign to attract entrants to the shipping industry, available at http://www.imo.org/en/OurWork/HumanElement/GoToSea/Pages/Default.aspx and http://www.imo.org/en/OurWork/HumanElement/GoToSea/Documents/Gotosea!campaign document.pdf\#search=ICS\%2FISF\%20presentations, accessed at 18.12.2018.

${ }^{23}$ Achieve gender equality and empower all women and girls, available at https://sdg-tracker.org/gender- equality, accessed at 15.02.2019.

24 Maritime Labour Convention (MLC), 2006, https://www.ilo.org/wcmsp5/groups/public/_-ed_norm/_-normes/documents/ normativeinstrument/wcms_090250.pdf

${ }^{25}$ UNIFEM Resources on Women, Peace and Security, available at: http://www.unwomen.org/en/digital-library/publications/ 2010/1/unifem-resources-on-women-peace-and-security, accessed on 09.03.2019. 
26 United Nations International Research and Training Institute for the Advancement of Women (UN-INSTRAW), available at https://www.unsystem.org/content/united-nations-international-research-and-training-institute-advancement-women-un-instraw

27 International Labour Organizations, available at https://www.ilo.org/global/about-the-ilo/lang—en/index.htm

${ }^{28}$ ILO's Employment Intensive Investment Programs in Timor-Leste promoting gender equality and women's empowerment, available at : https://www.ilo.org/jakarta/info/public/vid/WCMS_675934/lang_en/index.htm

${ }^{29}$ Resolutions adopted by the International Labour Conference (1919-2015), available at: https://www.ilo.org/global/about-theilo/how-the-ilo-works/departments-and-offices/jur/legal-instruments/WCMS_428590/lang_en/index.htm, accessed at 18.12.2018.

30 Maritime Labour Convention (MLC), 2006, https://www.ilo.org/wcmsp5/groups/public/—-ed_norm/—-normes/documents/ normativeinstrument/wcms_090250.pdf

${ }^{31}$ Gender equality promotion to combat trafficking in children and women, Technical Intervention Area Summary Notes: TIA-6, January, 2002, available at https://www.ilo.org/wcmsp5/groups/public/—-asia/_-ro-bangkok/documents/publication/wcms_160984.pdf, accessed at 15.02.2019.

32 Constitution of Georgia, available https://matsne.gov.ge/en/document/view/30346?publication=35

33 ILO's Employment Intensive Investment Programs in Timor-Leste promoting gender equality and women's empowerment, available at : https://www.ilo.org/jakarta/info/public/vid/WCMS_675934/lang_en/index.htm

${ }^{34}$ IMO TC 58/7/1, 2008, available at: https://www.transportstyrelsen.se/contentassets/96a86fba3e824620932c7545f4b9875a/587-1.pdf, accessed at 18.12.2018.

35 Women in maritime, http://www.imo.org/en/MediaCentre/HotTopics/women/Pages/default.aspx, accessed at 18.12.2018.

36 Seafarers Training and Certification Center, http://www.itfseafarers.org/ITI-women-seafarers.cfm

${ }^{37}$ LEPL- Teaching University- Batumi State Maritime Academy, http://bsma.edu.ge/

${ }^{38}$ Ltd Batumi Navigation Teaching University Georgia, http://bntu.edu.ge/index.php

${ }^{39}$ LLC-Batumi High Maritime Engineering School ANRI, http://www.mtc-anri.edu.ge

${ }^{40}$ Ltd Maritime training center "EQUATOR", www.equator.ge

${ }^{41}$ LEPL- Teaching University- Batumi State Maritime Academy http://bsma.edu.ge/sub-13/page/2-36/index.html

42 LEPL- Vocational Educational Center of LEPL- Teaching University- Batumi State Maritime Academy, http://bsma.edu.ge/ sub-14/page/2-38/index.html

43 Ports of Republic of Georgia, available http://mta.gov.ge/index.php?m=171\&parent_id=53

${ }^{44}$ LEPL- Maritime Transport Agency, http://mta.gov.ge/index.php?m=2

45 Constitution of Georgia, available https://matsne.gov.ge/en/document/view/30346?publication=35

${ }^{46} \mathrm{Law}$ of Georgia on Gender Equality, available https://matsne.gov.ge/en/document/download/91624/3/en/pdf

${ }^{47}$ Law of Georgia on the Elimination of All Forms of Discrimination available https://www.ilo.org/wcmsp5/groups/public/—ed_protect/—-protrav/—-ilo_aids/documents/legaldocument/wcms_361984.pdf

${ }^{48}$ Law of Georgia on Higher Education, available https://eqe.ge/res/docs/20180702141554untitled.pdf en/pdf

${ }^{49}$ Law of Georgia on Vocational Education and Training, available https://matsne.gov.ge/en/document/download/23608/12/

${ }^{50}$ Law of Georgia on the Education and Certification of Seafarers, available https://docplayer.net/7180358-Law-of-georgia-onthe-education-and-certification-of-seafarers.html

51 National Action Plan of Georgia for Implementation of the UN Security Council Resolutions on Women, Peace and Security 2018-2020, available at https://www.peacewomen.org/sites/default/files/Georgia\%20National\%20Action\%20Plan\%20(\%2020182020).pdf, accessed at 18.12.2018.

\section{Резюме}

\section{Мгеладзе М., Путкарадзе Н. Морська промисловість і роль жінок-моряків: нормативно-правова база.}

Морська промисловість із давніх часів уважалася лише чоловічою професією. Таке сприйняття поступово стало змінюватися. У сучасному світі жінки-моряки як і раніше становлять лише невелику частку морської робочої сили, що обмежує їх можливості для більш активної діяльності.

Оскільки сьогодні судноплавна галузь є більш глобальною та взаємозалежною, аніж колись, іiї успіх багато в чому залежить від здатності підтримувати людські ресурси. Така підтримка повинна включати прагнення залучати більше жінок. Проте для розширення прав і можливостей жінок у плані вступу в цю галузь потрібна розробка гендерної політики, а також міжнародної й національної нормативно-правової бази та підтримка в галузі освіти.

У даній статті роль жінок-моряків у морській промисловості розглядається шляхом виявлення перешкод, 3 якими вони зіштовхуються в ході своєї трудової діяльності.

Освітні, культурні, традиційні, релігійні й соціальні питання, дискримінація за ознакою статі, забобони, сексизм та сексуальні домагання, відхилення заяв жінок за ознакою статі, створення «штучних труднощів» для просування жінок-мореплавців на керівні посади, зайнятість на неналежних посадах, недостатній правовий захист - все це є бар'єром, що негативно позначається на залученні жінок до морської діяльності. Важливим також є питання про те, яким чином міжнародні правові й нормативні рамки в цей час вирішують цю проблему. Крім того, у статті визначаються й аналізуються ініціативи, висунуті міжнародними організаціями, які заохочують розширення утворення, підготовки й участі жінок-моряків у морській промисловості.

У статті представлено аналіз ситуації в області гендерної рівності стосовно жінок у Грузії. Він включає дослідження відповідного міжнародного морського права, грузинського законодавства, а також внутрішніх правил. Даються рекомендації про те, яким чином морська промисловість може розширювати можливості жінок у плані використання в цій галузі, особливо урахуванням того, що вона стає більш залежною від технологій.

Ключові слова: права людини, гендерна рівність, фемінізм, право, застосування, участь, утворення. 


\section{Резюме}

Мгеладзе М., Путкарадзе Н. Морская промышленность и роль женщин-моряков: нормативно-правовая база.

Морская промышленность с очень давних пор считалась лишь мужской профессией. Такое восприятие постепенно стало изменяться. В современном мире женщины-моряки по-прежнему составляют лишь небольшую долю морской рабочей силы, что ограничивает их возможности для более активной деятельности.

Поскольку сегодня судоходная отрасль является более глобальной и взаимосвязанной, чем когда-либо, ее успех во многом зависит от способности поддерживать человеческие ресурсы. Такая поддержка должна включать стремление привлекать больше женщин. Тем не менее, для расширения прав и возможностей женщин в плане вступления в эту отрасль требуется разработка гендерной политики, а также международной и национальной нормативно-правовой базы и поддержка в области образования.

В данной статье роль женщин-моряков в морской промышленности рассматривается путем выявления препятствий, с которыми они сталкиваются в ходе своей трудовой деятельности.

Образовательные, культурные, традиционные, религиозные и социальные вопросы, дискриминация по признаку пола, предрассудки, сексизм и сексуальные домогательства, отклонение заявлений женщин по признаку пола, создание «искусственных трудностей» для продвижения женщин-мореплавателей на руководящие должности, занятость на ненадлежащих должностях, недостаточная правовая защита - всё это является барьером, который негативно сказывается на вовлечении женщин в морскую деятельность. Важным также является вопрос о том, каким образом международные правовые и нормативные рамки в настоящее время решают эту проблему. Кроме того, в статье определяются и анализируются инициативы, выдвинутые международными организациями, которые поощряют расширение образования, подготовки и участия женщин-моряков в морской промышленности.

В статье представлен анализ ситуации в области гендерного равенства применительно к женщинам в Грузии. Он включает исследование соответствующего международного морского права, грузинского законодательства, а также внутренних правил. Даются рекомендации о том, каким образом морская промышленность может расширять возможности женщин в плане использования в этой отрасли, особенно с учетом того, что она становится более зависимой от технологий.

Ключевые слова: права человека, гендерное равенство, феминизм, право, применение, участие, образование.

\section{Summary}

Mariam Mgeladze, Nugzar Phutkaradze. The maritime industry and the role of women seafarers: a legal regulatory framework.

For thousands of years, it was believed that the maritime industry was reserved only for men. However, this perception has slowly begun to change. In today's world, women seafarers still represent a very small percentage of the maritime workforce, which has limited their opportunities to engage in more active employment role. Further, as today's shipping industry is more global and interconnected than ever before, its success depends largely on its ability to support its human resources. Such support must include a push from within to attract more women to its workforce. Nevertheless, empowering women to join this industry requires gender-based policy making, as well as international and national regulatory frameworks and educational support.

This article addresses the role of women seafarers in the maritime industry by examining and identifying obstacles they face during the course of their employment. Educational and cultural, traditional, religious, social matters, gender discrimination, prejudice, sexism and sexual harassment, rejection of women's application on the grounds of gender, creation of "artificial difficulties" to promote women mariners to senior positions, employment in inappropriate positions, insufficient legal protection, are wide range of barriers that have direct negative impact on women engagement into maritime business. As well as how international legal and regulatory frameworks presently address this issue. Furthermore, this article identifies and analyzes policy initiatives put forward by international organizations that encourage more industry education, training and participation for women seafarers. Additionally, this article will present a gender equality analysis of the present state of the industry with respect to women in the Republic of Georgia. This analysis includes a study of relevant international maritime law, Georgian law and domestic regulations and policies. Lastly, this article provides recommendations on how the maritime industry can empower women to join the industry, especially as it becomes more reliant on technology.

Key words: Human Rights, Gender equality, Feminism, Enforcement, Participation, Education. 